\title{
The Diagnostic Value of Soluble Urokinase Plasminogen Activator Receptor in Crimean-Congo Hemorrhagic Fever Disease in the Emergency Department
}

\author{
Acil Serviste Kırım Kongo Kanamalı Ateş Hastalığında Soluble Ürokinaz Plazminojen Aktivatör \\ Reseptörünün Tanısal Değeri
}

\author{
Kadir KÜÇÜKCERAN ${ }^{1}$ \\ (i) 0000-0001-9758-0803 \\ Ömer KARAŞAHIN ${ }^{2}$ \\ (D) 0000-0002-4245-1534 \\ Orhan DELICE ${ }^{3}$ \\ (D) 0000-0003-1629-4245 \\ Ali BATUR ${ }^{4}$ \\ (1) 0000-0002-2057-3215 \\ Sibel İBA YILMAZ ${ }^{2}$ \\ (D) 0000-0002-4123-0828 \\ Engin ŞEBIIN ${ }^{5}$ \\ (1) 0000-0001-9150-8069 \\ Mahmut SENYURT $^{5}$ \\ (D) 0000-0002-7041-540X
}

\begin{abstract}
${ }^{1}$ Necmettin Erbakan University Meram Faculty of Medicine Department of Emergency Medicine, Konya, Turkey
\end{abstract} ${ }^{2}$ Erzurum Regional Training and Research Hospital Department of Infectious Diseases and Clinical Microbiology, Erzurum, Turkey

${ }^{3}$ Erzurum Regional Training and Research Hospital Department of Emergency Medicine, Erzurum, Turkey

${ }^{4}$ Hacettepe University Faculty of Medicine Department of Emergency Medicine, Ankara, Turkey

${ }^{5}$ Erzurum Regional Training and Research Hospital Department of Biochemistry, Erzurum, Turkey

\section{Corresponding Author Sorumlu Yazar \\ Kadir KÜÇÜKCERAN \\ kadirkucukceran@hotmail.com}

Received / Geliş Tarihi : 03.11.2020 Accepted / Kabul Tarihi : 18.02.2021 Available Online /

Çevrimiçi Yayın Tarihi : 03.03.2021

\begin{abstract}
Aim: The urokinase-type plasminogen activator (uPA) system consists of a protease, a receptor (urokinase-type plasminogen activator receptor, uPAR), and inhibitors that can be expressed on various cell types. Previous literature shows that the amount of soluble urokinase-type plasminogen activator receptor (suPAR) secreted from affected cells is higher in Crimean-Congo hemorrhagic fever (CCHF) patients than in healthy controls. Thus, we aimed to investigate the diagnostic value of suPAR in the differential diagnosis of CCHF in emergency services.

Material and Methods: Individuals over 16 years old with a preliminary diagnosis of CCHF disease were divided into two groups as real time-polymerase chain reaction (RT-PCR) and/or IgM positive (CCHF group) and RT-PCR and/or IgM negative (control group).

Results: Eighty patients were included in this study. Forty patients with CCHF virus PCR and/or CCHF virus IgM were identified as CCHF group and 40 patients included as negative control group. The median age of the patients was 45 (range, 16-91) years, and 49 patients $(61.3 \%)$ were male. Leukocyte, platelet, and fibrinogen levels were significantly lower, while creatinine kinase, aPTT, and D-dimer levels were significantly higher in CCHF group. There was no statistically significant difference between the control group and CCHF group for SuPAR $(p=0.386)$. In addition, control group patients not diagnosed with CCHF were examined, brucellosis, influenza, and pneumonia were found to be the most common.

Conclusion: The use of suPAR as a biomarker in the differentiation of patients with similar findings in emergency services was investigated and found to have no diagnostic value.

Keywords: Hemorrhagic fever virus; Crimean-Congo; receptors; urokinase plasminogen activator; diagnosis.
\end{abstract}

ÖZ

Amaç: Ürokinaz tipi plazminojen aktivatör (uPA) sistemi, çeşitli hücrelerden salınan proteaz, reseptör (ürokinaz tipi plazminojen aktivatör reseptör, uPAR) ve inhibitörlerden oluşur. Literatürde, enfekte olan hücrelerden salgılanan solüble ürokinaz plazminojen aktivatör reseptörü (suPAR) düzeyinin Kırım-Kongo kanamalı ateşi (KKKA) hastalarında sağlıklı kontrollere göre daha yüksek olduğu gösterilmiştir. Bu çalışmada acil serviste KKKA'nın ayırıcı tanısında suPAR'ın tanısal değerinin araştırılması amaçlanmıştır.

Gereç ve Yöntemler: KKKA hastalığı ön tanısı alan 16 yaşın üstündeki bireyler gerçek zamanlı polimeraz zincir reaksiyonu (real time-polymerase chain reaction, RT-PCR) ve/veya IgM pozitif (KKKA grubu) ve RT-PCR ve/veya IgM negatif (kontrol grubu) olarak iki gruba ayrıldı. Bulgular: Bu çalışmaya 80 hasta dahil edildi. KKKA virus PCR ve/veya KKKA virus IGM'li 40 hasta KKKA grubu olarak ve 40 hasta negatif kontrol grup olarak belirlendi. Hastaların ortanca yaşı 45 (aralık, 16-91) yıldı ve $49(\% 61,3)$ hasta erkekti. KKKA grubunda lökosit, trombosit ve fibrinojen seviyeleri istatistiksel anlamlı olarak düşüktü, kreatinin kinaz, aPTT ve D-dimer seviyeleri ise istatistiksel anlamlı olarak yüksekti. SuPAR için kontrol grubu ile KKKA grubu arasında istatistiksel olarak anlamlı bir farklılık yoktu $(\mathrm{p}=0.386)$. Ayrica KKKA tanısı almayan kontrol grubu hastaları incelendiğinde, en sık bruselloz, influenza ve pnömoni olduğu bulundu.

Sonuç: Acil serviste benzer bulgulara sahip hastaların ayırt edilmesinde bir biyobelirteç olarak suPAR'ın kullanımı araştırıldı ve tanısal değeri olmadığı bulundu.

Anahtar kelimeler: Hemorajik ateş virüsü; Kırım-Kongo; reseptörler; ürokinaz plazminojen aktivatör; $\tan 1$. 


\section{INTRODUCTION}

Crimean-Congo hemorrhagic fever (CCHF) is a viral infectious disease with fatal outcomes that currently affects a wide geographical region, including Africa, Asia, Europe, and the Middle East $(1,2)$. Within the last 15 years, epidemics have been reported in Turkey at levels second only to those in Iran, Afghanistan, and Russia (3).

CCHF is a viral hemorrhagic fever disease that may present with fever and bleeding that can progress to shock and severe disease with high (10-40\%) mortality $(4,5)$. CCHF virus infection first leads to virus proliferation in dendritic cells and other local tissues, followed by virus migration to regional lymph nodes and subsequent spread to a wide variety of tissues and organs, including the liver, spleen, and lymph nodes via lymphocytes and monocytes (1). Biomarkers are urgently needed for the diagnosis and prognosis of this high-mortality disease, and many studies in the literature have addressed this purpose (5-10).

One potential biomarker is the urokinase-type plasminogen activator (uPA) system. The uPA system consists of a protease, a receptor (urokinase-type plasminogen activator receptor, uPAR), and inhibitors that can be expressed on various cell types, including neutrophils, lymphocytes, monocytes/macrophages, and endothelial and tumor cells. The soluble form of the uPAR is defined as the soluble urokinase-type plasminogen activator receptor (suPAR) and involved in immunological functions ranging from cell adhesion, migration, and chemotaxis to proteolysis, immune activation, tissue remodeling, invasion, and signal transduction $(11,12)$. The available literature indicates that suPAR secretion is greater from lymphocytes and monocytes from patients with CCHF than from healthy controls (13).

The aim of the present study was to investigate the diagnostic value of suPAR in differential diagnosis of CCHF at emergency medicine.

\section{MATERIAL AND METHODS}

The participants in this study, held from June to September 2018, were over the age of 16 admitted to our hospital's emergency service who had received a preliminary diagnosis of CCHF disease, had been diagnosed in the relevant clinics, and agreed to participate. Patients less than 16 years of age and who did not agree to participate in the study were not included. The study was approved by the Ethics Committee of Erzurum Regional Training and Research Hospital (05.03.2018, 05-35).

The medical records of the patients were retrospectively reviewed. Clinical findings and laboratory results upon admittance to emergency services were recorded. Realtime polymerase chain reaction (RT-PCR) (QiagenR CCHFV viral RNA KIT, Qiagen, Hilden Germany) and CCHF virus IgM tests with the indirect immunofluorescence test method were studied in the reference laboratory. RT-PCR and/or IgM positivity were used for the definitive diagnosis of the CCHF cases. Patients were classified as serum RT-PCR and/or IgM positive (CCHF group) and RT-PCR and/or IgM negative (control group). The clinical diagnoses made for the patients in the control group were recorded.

The serum and plasma of the blood samples taken for the examination of the patients in the emergency service were used. After the samples were taken into tubes without anticoagulants, they were kept at room temperature for 30 minutes in line with the ELISA kit instructions we used. Then they were centrifuged at $3000 \mathrm{rpm}$ for 20 minutes at $+4{ }^{\circ} \mathrm{C}$. Serum remaining on top of tubes was transferred to Eppendorf tubes and lifted to $-80{ }^{\circ} \mathrm{C}$ by the date of the study. SuPAR was manually studied using the ELISA Kit (cat.no: SL2132Hu) according to the kit procedures. ELISA reader was performed with ChemWell ${ }^{\circledR} 2910$ Automated EIA and Chemistry Analyzer (Awareness Technology, USA).

\section{Statistical Analysis}

Statistical analyses were made with the SPSS v.20.0 package. Normality assumption was evaluated using histograms and the Kolmogorov-Smirnov test. Differences between two groups were analyzed using Student's t-test for the quantitative variables and the Mann-Whitney U test for the variables not distributed normally. Categorical variables were analyzed with Pearson chi-square and Fisher's exact test. Spearman correlation analysis was performed to evaluate the correlation between suPAR and other parameters. Quantitative data were expressed as median, $25 \%-75 \%$ quartiles, minimum-maximum or mean \pm standard deviation, and categorical variables as frequency (percentage). A two-sided p value of 0.05 was considered as statistically significant.

\section{RESULTS}

Two-hundred and nine patients who met the inclusion criteria were identified. While 71 of these 209 patients were diagnosed with CCHF, 138 of them were not. According to the number of kits, 80 patients admitted to the emergency service with a CCHF pre-diagnosis, 40 patients for the CCHF group and 40 for the control group, were selected randomly.

The median age of the patients was 45 (range, 16-91) years, and $49(61.3 \%)$ patients were male. Forty patients with positive PCR and/or IgM results for CCHF virus were identified as the CCHF group, and 40 patients with disease symptoms but without CCHF positivity were designated as the negative control group. Median age was 50.5 (range, 16-91) years in control group, and $27(67.5 \%)$ of the patients were male and 13 (32.5\%) were female; while median age was 43.5 (range, 16-91) years in CCHF group, and $22(55.0 \%)$ of the patients were male and $18(45.0 \%)$ were female. There was no statistically significant difference between CCHF and control groups in terms of age $(\mathrm{p}=0.988)$ and gender $(\mathrm{p}=0.251)$.

The comparison of laboratory values between these two groups is presented in Table 1. Creatinine kinase, D-dimer, aPTT, fibrinogen, leukocyte, and platelet values were found to be significantly different between the CCHF and control groups. Leukocyte, platelet, and fibrinogen levels were significantly lower in the CCHF group ( $<<0.001$, $\mathrm{p}=0.006, \quad \mathrm{p}<0.001$; respectively). Creatinine kinase, activated partial thromboplastin time (aPTT), and D-dimer levels were significantly higher in the CCHF group ( $p=0.001, p=0.005, p=0.013$; respectively). No statistically significant difference was detected in the SuPAR levels between the control group and the CCHF group $(\mathrm{p}=0.386$ ). The suPAR levels of the CCHF patients were positively correlated with alanine aminotransferase (ALT) and aPTT levels $(\mathrm{r}=0.295, \mathrm{p}=0.008$, and $\mathrm{r}=0.309, \mathrm{p}=0.006$, respectively). 
Table 1. Comparison of laboratory parameters in CCHF and control groups

\begin{tabular}{lccccccc}
\hline & \multicolumn{3}{c}{ Control $(\mathbf{n}=\mathbf{4 0})$} & \multicolumn{3}{c}{ CCHF $(\mathbf{n = 4 0})$} & p \\
\cline { 2 - 6 } & Median & Q1 - Q3 & Min - Max & Median & Q1 - Q3 & Min - Max & 0.105 \\
\hline AST (IU/L) & 47.5 & $22.5-97.5$ & $15-913$ & 53.5 & $32.0-148.75$ & $18-914$ & 0.516 \\
ALT (IU/L) & 36.5 & $16.0-79.5$ & $7-853$ & 36.5 & $19.0-88.5$ & $15-604$ \\
LDH (IU/L) & 303.0 & $235.75-376.25$ & $125-1426$ & 298.0 & $229.5-496$ & $116-1995$ & 0.427 \\
CPK (mg/dL) & 108.5 & $66-203$ & $20-2492$ & 247.5 & $128.25-474.75$ & $38-4003$ & $\mathbf{0 . 0 0 1}$ \\
WBC $\left(10^{3} / \mu L\right)$ & 6539 & $4001-9750$ & $2254-14440$ & 2736 & $2268.5-3549.5$ & $802-13490$ & $<\mathbf{0 . 0 0 1}$ \\
PLT $\left(10^{3} / \mu L\right)$ & 130100 & $106400-148800$ & $33000-307200$ & 107950 & $61500-128900$ & $6780-263500$ & $\mathbf{0 . 0 0 6}$ \\
CRP (mg/dL) & 6.33 & $1.33-11.80$ & $0.32-21.00$ & 1.61 & $0.32-3.63$ & $0.30-8.08$ & $<\mathbf{0 . 0 0 1}$ \\
aPTT (second) & 26.4 & $24.0-28.6$ & $20.3-38.3$ & 28.3 & $26.1-33.9$ & $22.0-53.5$ & $\mathbf{0 . 0 0 5}$ \\
D-dimer & 1.33 & $0.92-3.34$ & $0.19-32.7$ & 2.45 & $1.4-5.09$ & $0.19-80.0$ & $\mathbf{0 . 0 1 3}$ \\
INR & 1.13 & $1.05-1.22$ & $0.89-1.90$ & 1.1 & $1.01-1.19$ & $0.92-1.82$ & 0.128 \\
Creatinine (mg/dl) & 0.89 & $0.77-1.2$ & $0.45-3.57$ & 0.79 & $0.73-0.95$ & $0.63-2.72$ & 0.067 \\
Fibrinogen (mg/dl) & 298 & $250-384$ & $177-605$ & 223 & $204.75-265$ & $118-900$ & $<\mathbf{0 . 0 0 1}$ \\
suPAR (pg/ml) & 4740 & $3775-6905$ & $2615-13935$ & 4477.5 & $3108.75-6410$ & $1885-12985$ & 0.386 \\
\hline
\end{tabular}

CCHF: Crimean-Congo Hemorrhagic Fever, Q1-Q3: $25^{\text {th }}-75^{\text {th }}$ percentile, Min-Max: Minimum-Maximum, AST: aspartate aminotransferase, ALT: alanine aminotransferase, LDH: lactate dehydrogenase, CPK: creatine phosphokinase, WBC: white blood cells, PLT: thrombocyte count, CRP: C-reactive protein, aPTT: activated partial thromboplastin time, INR: international normalized rate, suPAR: soluble urokinase-type plasminogen activator receptor

A weak positive correlation was also found between suPAR and both aspartate aminotransferase (AST) and lactate dehydrogenase $(\mathrm{LDH})$ levels $(\mathrm{r}=0.264, \mathrm{p}=0.018$, and $\mathrm{r}=0.231, \mathrm{p}=0.040$, respectively, Table 2).

The most common clinical findings in CCHF patients were fever $(n=38,95.0 \%)$, headache $(n=37,92.5 \%)$, myalgia $(\mathrm{n}=37,92.5 \%)$, weakness, nausea and vomiting $(\mathrm{n}=23$, $57.5 \%)$. However, no statistically significant difference was found between the control group and CCHF patients in terms of clinical findings (Table 3).

The control group patients had brucellosis $(n=7,17.5 \%)$, influenza $(n=7,17.5 \%)$, and pneumonia $(n=7,17.5 \%)$ as the most common diagnoses (Table 4).

Table 2. Correlation of suPAR value and some biomarkers in CCHF patients

\begin{tabular}{lcc}
\hline & \multicolumn{2}{c}{ suPAR } \\
\cline { 2 - 3 } & $\mathbf{r}$ & $\mathbf{p}$ \\
\hline AST & $\mathbf{0 . 2 6 4}$ & $\mathbf{0 . 0 1 8}$ \\
ALT & $\mathbf{0 . 2 9 5}$ & $\mathbf{0 . 0 0 8}$ \\
LDH & $\mathbf{0 . 2 3 1}$ & $\mathbf{0 . 0 4 0}$ \\
CPK & 0.048 & 0.670 \\
WBC & 0.051 & 0.656 \\
PLT & -0.034 & 0.762 \\
CRP & 0.053 & 0.641 \\
aPTT & $\mathbf{0 . 3 0 9}$ & $\mathbf{0 . 0 0 6}$ \\
D-dimer & 0.030 & 0.792 \\
INR & 0.013 & 0.911 \\
Creatinine & 0.126 & 0.267 \\
Fibrinogen & -0.040 & 0.726 \\
Sedimentation & -0.094 & 0.407 \\
\hline suPAR: soluble urokinase-type plasminogen activator & receptor, AST: \\
aspartate aminotransferase, ALT: alanine aminotransferase, LDH: lactate \\
dehydrogenase, CPK: creatine phosphokinase, WBC: white blood cells, PLT: \\
thrombocyte count, CRP: C-reactive protein, aPTT: activated partial \\
thromboplastin time, INR: international normalized rate
\end{tabular}

Table 3. Comparison of clinical findings in $\mathrm{CCHF}$ and control groups, n (\%)

\begin{tabular}{lccc}
\hline Clinical findings & $\begin{array}{c}\text { Control } \\
(\mathbf{n}=\mathbf{4 0})\end{array}$ & $\begin{array}{c}\text { CCHF } \\
(\mathbf{n}=\mathbf{4 0})\end{array}$ & $\mathbf{p}$ \\
\hline Fever & $35(87.5)$ & $38(95.0)$ & $0.432^{*}$ \\
Hypotension & $6(15.0)$ & $3(7.5)$ & $0.481^{*}$ \\
Tachycardia & $3(7.5)$ & $3(7.5)$ & $0.999^{*}$ \\
Blur of Consciousness & $2(5.0)$ & $3(7.5)$ & $0.999^{*}$ \\
Ecchymosis & $2(5.0)$ & $2(5.0)$ & $0.999^{*}$ \\
Bleeding & $4(10.0)$ & $3(7.5)$ & $0.999^{*}$ \\
Headache & $36(90.0)$ & $37(92.5)$ & $0.999^{*}$ \\
Myalgia & $32(80.0)$ & $37(92.5)$ & $0.105^{* *}$ \\
Nausea-vomiting & $19(47.5)$ & $23(57.5)$ & $0.370^{* *}$ \\
Diarrhea & $8(20.0)$ & $12(30.0)$ & $0.302^{* *}$ \\
Abdominal pain & $13(32.5)$ & $16(40.0)$ & $0.485^{* *}$ \\
\hline *: Fisher's exact test, ${ }^{* *}:$ Pearson chi-square test &
\end{tabular}

Table 4. Distribution of final diagnoses of the control group

\begin{tabular}{lc} 
Final diagnose & $\mathbf{n}(\boldsymbol{\%})$ \\
\hline Brucellosis & $7(17.5)$ \\
Flu & $7(17.5)$ \\
Pneumonia & $7(17.5)$ \\
Isolated thrombocytopenia & $4(10.0)$ \\
Lower gastrointestinal tract bleeding & $3(7.5)$ \\
Acute gastroenteritis & $2(5.0)$ \\
Drug intoxication & $2(5.0)$ \\
Urinary tract infection & $2(5.0)$ \\
Acute hepatitis A & $1(2.5)$ \\
Acute pancreatitis & $1(2.5)$ \\
Q Fever & $1(2.5)$ \\
ITP & $1(2.5)$ \\
Acute cholecystitis & $1(2.5)$ \\
Skin, soft tissue infection & $1(2.5)$
\end{tabular}




\section{DISCUSSION}

CCHF cases may show some clinical symptoms, including leukopenia, leukocytosis, anemia, thrombocytopenia, elevated AST and ALT levels, increased LDH levels, raised creatine phosphokinase (CPK) levels, prolonged prothrombin time (PT), aPTT levels, increased D-dimer levels, and elevated amounts of fibrin breakdown products (5-10). We detected elevations in thrombocytopenia, leukopenia, CK, and D-dimer levels in our CCHF group, as well as reduced levels of fibrinogen. However, these laboratory findings are known to be non-specific for CCHF (14).

There is need for an easy, inexpensive, and perfect single biomarker for the diagnosis, follow-up, and prognosis of diseases like CCHF, and studies have been conducted to search for this type of biomarker $(15,16)$. The aim of our study was to determine the diagnostic value of suPAR in the differential diagnosis of laboratory samples and clinically similar patients in the emergency department.

Activation of lymphocytes, monocytes, and macrophages and the resulting excess secretion of cytokines have been reported to play an important role in the pathogenesis and prognosis of CCHF, as in other viral hemorrhagic diseases. Infected monocytes and lymphocytes have been shown to express high cell surface uPAR levels, and the serum suPAR level may be associated with the number of infected cells in the organism. For this reason, suPAR levels are predicted to be higher in CCHF-virus-infected patients than in healthy controls $(17,18)$.

The expression of suPAR has been shown to increase during endotoxemia (19). Also, although its diagnostic value is lower than that of procalcitonin and C-reactive protein in sepsis $(61.2 \%$ of which is bacterial), the suPAR level has been reported to increase during sepsis (20). In the cerebrospinal fluids of patients with proven central nervous system infections, suPAR levels were statistically significantly higher than in patients without infection (21). In patients with CCHF infection, compared to healthy controls, suPAR levels were found to be significantly higher, and a high diagnostic value was obtained with a threshold value of $3.06 \mathrm{ng} / \mathrm{ml}$ (13).

Biomarkers are also known to be important in predicting morbidity and mortality. In the study conducted by Yilmaz et al. (13), they found that suPAR levels were shown to have a prognostic significance (cut-off, $10.6 \mathrm{ng} / \mathrm{mL}$ ) for mortality in patients with CCHF. Also, suPAR concentrations may reflect the severity of infection in other diseases. For example, suPAR levels are associated with poor outcomes in communicable and non-communicable diseases and with high mortality in malaria, tuberculosis, human immunodeficiency virus infection, and some forms of cancer (22-25). As seen in our study, no specific clinical findings and biomarkers were identified for CCHF, although suPAR has been indicated in the literature to be a diagnostic and prognostic biomarker that differentiates between patients with CCHF and healthy individuals (13). However, we found no statistically significant difference between our patients with CCHF and the control group in terms of suPAR. This situation is thought to reflect the fact that the control group selected in our study had diseases that could be confused with CCHF, both clinically and in laboratory findings. In our study, the most common diagnoses in the control group were again infectious diseases such as brucellosis, influenza, and pneumonia, and suPAR levels have been reported to increase in infectious diseases like pneumonia, brucellosis, pancreatitis, sepsis, tuberculosis, and malaria (22,26-30). In a previous study that reported a significant difference between CCHF patients and healthy individuals, a positive correlation was found between suPAR and the ALT, aPTT, AST, and LDH values in CCHF patients, as in our study (13). This result suggests that suPAR acts as another nonspecific biomarker of infection and may be useful in diagnostic algorithms.

This study had some limitations, including the small number of enrolled patients, its design as a single-center study, and the lack of a healthy control group.

\section{CONCLUSION}

This study confirms the importance of isolating patients who come to the emergency service with clinical and laboratory findings resembling CCHF infection in terms of disease control and referring them to the relevant clinic. However, the use of suPAR as a biomarker appears to have no diagnostic value in differentiating patients with similar findings in clinical practice in the emergency department. Nevertheless, suPAR could be useful as a parameter in algorithm development due to its correlation with other non-specific biomarkers.

Ethics Committee Approval: The study was approved by the Ethics Committee of Erzurum Regional Training and Research Hospital (05.03.2018, 05-35).

Conflict of Interest: None declared by the authors.

Financial Disclosure: None declared by the authors.

Acknowledgements: None declared by the authors.

Author Contributions: Idea/Concept: KK, ÖK; Design: ÖK; Data Collection/Processing: ÖK; Analysis/Interpretation: EŞ, MŞ; Literature Review: KK, ÖK; Drafting/Writing: KK, ÖK; Critical Review: KK, ÖK, OD, AB, SIY.

\section{REFERENCES}

1. Ergonul O. Crimean-Congo hemorrhagic fever virus: new outbreaks, new discoveries. Curr Opin Virol. 2012;2(2):215-20.

2. Al-Abri SS, Abaidani IA, Fazlalipour M, Mostafavi E, Leblebicioglu H, Pshenichnaya N, et al. Current status of Crimean-Congo haemorrhagic fever in the World Health Organization Eastern Mediterranean Region: issues, challenges, and future directions. Int J Infect Dis. 2017;58:82-9.

3. Leblebicioglu H, Ozaras R, Fletcher TE, Beeching NJ, ESCMID Study Group for Infections in Travellers and Migrants (ESGITM). Crimean-Congo haemorrhagic fever in travellers: A systematic review. Travel Med Infect Dis. 2016;14(2):73-80.

4. Yilmaz G, Koksal I, Topbas M, Yilmaz H, Aksoy F. The effectiveness of routine laboratory findings in determining disease severity in patients with CrimeanCongo hemorrhagic fever: severity prediction criteria. J Clin Virol. 2010;47(4):361-5. 
5. Kilinc C, Gückan R, Capraz M, Varol K, Zengin E, Mengeloglu Z, et al. Examination of the specific clinical symptoms and laboratory findings of Crimean-Congo hemorrhagic fever. J Vector Borne Dis. 2016;53(2):162-7.

6. Dreshaj S, Ahmeti S, Ramadani N, Dreshaj G, Humolli I, Dedushaj I. Current situation of Crimean-Congo hemorrhagic fever in Southeastern Europe and neighboring countries: a public health risk for the European Union? Travel Med Infect Dis. 2016;14(2):81-91.

7. Ergonul O, Celikbas A, Baykam N, Eren S, Dokuzoguz B. Analysis of risk-factors among patients with Crimean-Congo haemorrhagic fever virus infection: severity criteria revisited. Clin Microbiol Infect. 2006;12(6):551-4.

8. Yilmaz GR, Buzgan T, Irmak H, Safran A, Uzun R, Cevik MA, et al. The epidemiology of Crimean-Congo hemorrhagic fever in Turkey, 2002-2007. Int J Infect Dis. 2009;13(3):380-6.

9. Mostafavi E, Pourhossein B, Chinikar S. Clinical symptoms and laboratory findings supporting early diagnosis of Crimean-Congo hemorrhagic fever in Iran. J Med Virol. 2014 Jul;86(7):1188-92.

10. Owaysee Osquee H, Pourjafar H, Taghizadeh S, Haghdoost M, Ansari F. Laboratory features of 160 CCHF confirmed cases in Zabol of Iran: A 10-year study. J Infect. 2017;74(4):418-20.

11. Ploug M, Rønne E, Behrendt N, Jensen AL, Blasi F, Danø K. Cellular receptor for urokinase plasminogen activator. Carboxyl-terminal processing and membrane anchoring by glycosyl-phosphatidylinositol. J Biol Chem. 1991;266(3):1926-33.

12. Eugen-Olsen J. suPAR - a future risk marker in bacteremia. J Intern Med. 2011;270(1):29-31.

13. Yilmaz G, Mentese A, Kaya S, Uzun A, Karahan SC, Koksal I. The diagnostic and prognostic significance of soluble urokinase plasminogen activator receptor in Crimean-Congo hemorrhagic fever. J Clin Virol. 2011;50(3):209-11.

14. Tanyel E, Sunbul M, Fletcher TE, Leblebicioglu H. Aetiology of PCR negative suspected Crimean-Congo hemorrhagic fever cases in an endemic area. Pathog Glob Health. 2016;110(4-5):173-7.

15. Büyüktuna SA, Doğan HO, Unlusavuran M, Bakir M. An evaluation of the different biomarkers to discriminate bleeding in Crimean-Congo hemorrhagic fever. Ticks Tick Borne Dis. 2019;10(5):997-1002.

16. Akinci E, Bodur H, Sunbul M, Leblebicioglu H. Prognostic factors, pathophysiology and novel biomarkers in Crimean-Congo hemorrhagic fever. Antiviral Res. 2016;132:233-43.

17. Donadello K, Scolletta S, Covajes C, Vincent JL. suPAR as a prognostic biomarker in sepsis. BMC Med. 2012;10:2.

18. Bustamante A, García-Berrocoso T, Penalba A, Giralt D, Simats A, Muchada M, et al. Sepsis biomarkers reprofiling to predict stroke-associated infections. J Neuroimmunol. 2017;312:19-23.

19. Ostrowski SR, Plomgaard P, Fischer CP, Steensberg A, Møller K, Høyer-Hansen G, et al. Interleukin-6 infusion during human endotoxaemia inhibits in vitro release of the urokinase receptor from peripheral blood mononuclear cells. Scand J Immunol. 2005;61(2):197206.

20. Kofoed K, Andersen O, Kronborg G, Tvede M, Petersen J, Eugen-Olsen J, et al. Use of plasma Creactive protein, procalcitonin, neutrophils, macrophage migration inhibitory factor, soluble urokinase-type plasminogen activator receptor, and soluble triggering receptor expressed on myeloid cells1 in combination to diagnose infections: a prospective study. Crit Care. 2007;11(2):R38.

21. Ostergaard C, Benfield T, Lundgren JD, Eugen-Olsen J. Soluble urokinase receptor is elevated in cerebrospinal fluid from patients with purulent meningitis and is associated with fatal outcome. Scand J Infect Dis. 2004;36(1):14-9.

22. Ostrowski SR, Ullum H, Goka BQ, Høyer-Hansen G, Obeng-Adjei G, Pedersen BK, et al. Plasma concentrations of soluble urokinase-type plasminogen activator receptor are increased in patients with malaria and are associated with a poor clinical or a fatal outcome. J Infect Dis. 2005;191(8):1331-41.

23. Eugen-Olsen J, Gustafson P, Sidenius N, Fischer TK, Parner J, Aaby P, et al. The serum level of soluble urokinase receptor is elevated in tuberculosis patients and predicts mortality during treatment: a community study from Guinea-Bissau. Int $\mathrm{J}$ Tuberc Lung Dis. 2002;6(8):686-92.

24. Ostrowski SR, Piironen T, Høyer-Hansen G, Gerstoft J, Pedersen BK, Ullum H. High plasma levels of intact and cleaved soluble urokinase receptor reflect immune activation and are independent predictors of mortality in HIV-1-infected patients. J Acquir Immune Defic Syndr. 2005;39(1):23-31.

25. Erkut N, Mentese A, Ozbas HM, Ermantaş N, Sümer A, Örem A, et al. The prognostic significance of soluble urokinase plasminogen activator receptor in acute myeloid leukemia. Turk J Haematol. 2016;33(2):135-40.

26. Karsen H, Cesur S, Karaağaç L, Binici I, Fidan Y, Oğüş E, et al. Can mannose-binding lectin and plasma level of soluble urokinase receptor be used in diagnosis and treatment monitorization of brucellosis patients? Mikrobiyol Bul. 2012;46(3):519-21.

27. Tsai PK, Tsao SM, Yang WE, Yeh CB, Wang HL, Yang SF. Plasma soluble urokinase-type plasminogen activator receptor level as a predictor of the severity of community-acquired pneumonia. Int $\mathrm{J}$ Environ Res Public Health. 2019;16(6):1035.

28. Nikkola A, Aittoniemi J, Huttunen R, Rajala L, Nordback I, Sand J, et al. Plasma level of soluble urokinase-type plasminogen activator receptor predicts the severity of acute alcohol pancreatitis. Pancreas 2017;46(1):77-82.

29. Huang Q, Xiong H, Yan P, Shuai T, Liu J, Zhu L, et al. The diagnostic and prognostic value of suPAR in patients with sepsis: A systematic review and metaanalysis. Shock. 2020;53(4):416-25.

30. Schulman H, Niward K, Abate E, Idh J, Axenram P, Bornefall A, et al. Sedimentation rate and suPAR in relation to disease activity and mortality in patients with tuberculosis. Int $\mathbf{J}$ Tuberc Lung Dis. 2019;23(11):1155-61. 